\title{
Antimicrobial and Dyeing Properties of Reactive Dyes with Thiazolidinon-4-one Nucleus
}

\author{
Hailemichael Ayalew, ${ }^{1}$ Gebremedihin Reda, ${ }^{2}$ Tsegaye Gashaw, ${ }^{3}$ \\ Neelaiah Babu, ${ }^{1}$ and Raj Kumar Upadhyay ${ }^{1}$ \\ ${ }^{1}$ Department of Chemistry, College of Natural and Computational Sciences, Haramaya University, \\ P.O. Box 276, Haramaya, Ethiopia \\ ${ }^{2}$ Department of Chemistry, College of Natural and Computational Sciences, Mekelle University, Ethiopia \\ ${ }^{3}$ Department of Chemistry, College of Natural and Computational Sciences, Assosa University, Ethiopia
}

Correspondence should be addressed to Hailemichael Ayalew; hailemichael@haramaya.edu.et

Received 19 December 2013; Accepted 14 January 2014; Published 4 March 2014

Academic Editors: P. S. Andrada and H. G. Bonacorso

Copyright (C) 2014 Hailemichael Ayalew et al. This is an open access article distributed under the Creative Commons Attribution License, which permits unrestricted use, distribution, and reproduction in any medium, provided the original work is properly cited.

Four imines, the condensation products of 2,4-dioxo-4-phenylbutanal with four primary amines, were condensed with mercapto acetic acid to obtain thiazolidinon-4-ones which on subsequent condensation with vanillin and isatin separately yielded eight thiazolidin-4-one derivatives. The chemical structures of the synthesized compounds were elucidated by elemental analysis, molecular weight determination, IR and ${ }^{1} \mathrm{H}$ and ${ }^{13} \mathrm{C}$ NMR spectral measurements. Antibacterial and antifungal properties were studied in vitro against two bacteria and two fungi. The dyeing potential of synthesized reactive dyes was investigated with regard to silk, wool, cotton, and polyester fabrics under hot and cold dyeing conditions.

\section{Introduction}

A small heterocyclic ring containing nitrogen and sulphur has been under investigation for pretty long time owing to their potential biological features. Among these heterocyclics, thiazolidinones having thiazol nucleus have been reported to display wide spectrum ofimportant biological activities leading to their medicinal usage such as anticancer [1], antitubercular [2], anti-HIV [3], analgesic [4], anti-inflammatory [4], ulcerogenic [5], sedative [6], antiviral [7], CNS depressant [7], hypnotic [8], antithyroidal [9], antibacterial [10, 11], and antifungal $[12,13]$. Besides the pivotal role of thiazolidinones in the field of medicinal science, their many derivatives, exhibiting herbicidal [14], pesticidal [15], and insecticidal [15] properties, have significant role in agriculture. The dyeing [16-18] and ligation [19] properties of thiazolidinones have also been reported. Reactive dyes believed to form homopolar bonds with textile substrates $[16,17]$ with special finishing capabilities are currently an area of active research. The synthesized thiazolidinone derivatives exhibiting antimicrobial properties and possessing several auxochromic and chromophoric groups reactive with synthetic (cellulose) and natural (protein) fabrics tempted us to evaluate their dyeing potentials with silk, wool, cotton, and polyester fabrics with simultaneous antimicrobial finishing of the textiles.

\section{Results and Discussion}

The synthesis of compounds $\mathbf{9 a}-\mathbf{h}$ is based on the synthetic routes shown in Scheme 1. Commercially available Benzoyl acetone (1) was oxidized into its glyoxal, 2,4dioxo-4-phenylbutanal (2), by using selenium dioxide in ethanol. Then, the reaction of glyoxal (2) with substituted anilines such as $\mathrm{p}-\mathrm{NO}_{2}, \mathrm{p}-\mathrm{OH}, \mathrm{p}-\mathrm{OCH}_{3}$, and $\mathrm{p}-\mathrm{N}\left(\mathrm{CH}_{3}\right)_{2}$ in dry ethanol yielded 3-oxo-3-phenylpropanal azomethines (4) which on cyclocondensation with thioglycolic acid in dry benzene provided 2-(3-oxo-3-phenylpropanal)-3(substituted aryl)-1-thiazolidin-4-ones. The final compounds $\mathbf{9 a}-\mathbf{h}$ were prepared by the condensation reaction of two carbonyl compounds namely vanillin and isatin in dry methanol using sodium acetate as catalyst as well as dehydrating agent. 


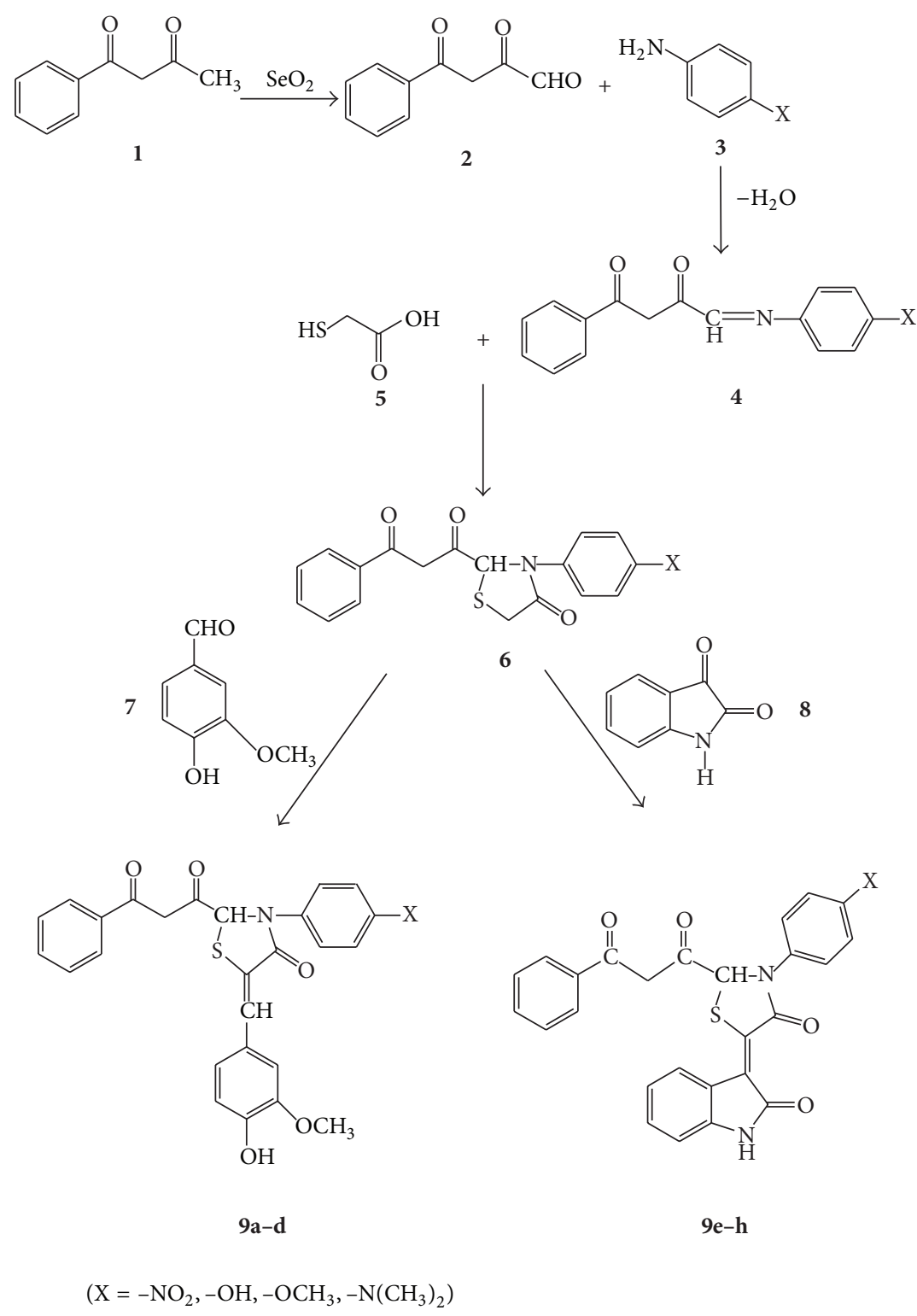

Scheme 1: Synthetic routes to intermediates $(2,4,6)$ and target compounds $9 \mathbf{a}-\mathbf{h}$.

It has been demonstrated that these reaction conditions are very useful to synthesize titled compounds with fairly high yields in relative short reaction times and easy work-up procedures. The IR, ${ }^{1} \mathrm{H}$ NMR, ${ }^{13} \mathrm{C}$ NMR spectral, molecular weight and elemental analysis data (Table 1) obtained are fairly consistent with the molecular formulae and structures of the synthesized compounds (Scheme 1).

2.1. Antimicrobial Activity. Antimicrobial tests of the synthesized thiazolidinone derivatives conducted on one Gramnegative (Escherichia coli) and one Gram-positive (Staphylococcus aureus) bacterial and selected fungi, Aspergillus niger and Rhizoctonia bataticola, revealed dose dependent activities of the new products. Compounds $\mathbf{9 a}, \mathbf{9 b}, \mathbf{9 c}$, and 9d were found to possess significant antibacterial activity against $S$. aureus bacterium as compared with standard drug
Ampicillin. Compounds 9a, 9b, 9c, and 9d exhibiting greater fungicidal activity than reference drug Bavistin against $A$. niger could be considered as highly selective for this fungus. All the new products $(\mathbf{9} \mathbf{a}-\mathbf{h})$, however, showed moderate antifungal properties against $R$. bataticola (Table 2).

2.2. Dyeing Properties of Dyes. Since the stability and colour intensity of thiazolidinone dyes depend on $\mathrm{pH}$, the concentration of sulfuric acid necessary for producing maximum colour intensity of each of the synthesized dyes has been determined spectrophotometrically as $6533 \mathrm{ppm}, 8166 \mathrm{ppm}$, $8166 \mathrm{ppm}, 6533 \mathrm{ppm}, 3266 \mathrm{ppm}, 9800 \mathrm{ppm}, 4900 \mathrm{ppm}$, and $8166 \mathrm{ppm}$ for 9a, 9b, 9c, 9d, 9e, 9f, 9g, and 9h, respectively. Dye exhaustion and fixation data (Table 3 ) clearly shows that all the dyes used have highest dyeing potential in cold dyeing treatment for all the four types of fibres most probably owing 
TABle 1: Physicochemical properties of dyes.

\begin{tabular}{|c|c|c|c|c|c|c|c|c|c|c|}
\hline \multirow{2}{*}{ Dye } & \multirow{2}{*}{ m.f } & \multirow{2}{*}{$p$-substitu ents } & \multirow{2}{*}{ Yield (\%) } & \multirow{2}{*}{ m.p $\left({ }^{\circ} \mathrm{C}\right)$} & \multirow{2}{*}{ m.w., calcd. (found) } & \multicolumn{4}{|c|}{ Elemental analysis (\%): calcd. (found) } & \multirow{2}{*}{$\lambda_{\max }(\mathrm{nm})$} \\
\hline & & & & & & $\mathrm{C}$ & $\mathrm{H}$ & $\mathrm{N}$ & S & \\
\hline $9 a$ & $\mathrm{C}_{26} \mathrm{H}_{20} \mathrm{~N}_{2} \mathrm{O}_{7} \mathrm{~S}$ & $p-\mathrm{NO}_{2}$ & 65 & 96 & $504(492.37)$ & $61.90(60.84)$ & $3.97(3.85)$ & $5.56(5.94)$ & $6.35(6.41)$ & 384 \\
\hline $9 b$ & $\mathrm{C}_{26} \mathrm{H}_{21} \mathrm{NO}_{6} \mathrm{~S}$ & $p-\mathrm{OH}$ & 72 & 195 & $475(470.55)$ & $65.68(65.07)$ & $4.42(4.41)$ & $2.95(3.29)$ & $6.74(6.27)$ & 356 \\
\hline 9c & $\mathrm{C}_{27} \mathrm{H}_{23} \mathrm{NO}_{6} \mathrm{~S}$ & $p-\mathrm{OCH}_{3}$ & 74 & 39 & 489 (492.37) & $66.26(65.67)$ & $4.70(4.71)$ & $2.86(2.61)$ & $6.54(6.95)$ & 310 \\
\hline 9d & $\mathrm{C}_{22} \mathrm{H}_{26} \mathrm{~N}_{2} \mathrm{O}_{5} \mathrm{~S}$ & $p-\mathrm{N}\left(\mathrm{CH}_{3}\right)$ & 84 & 59 & $502(492.37)$ & $66.93(66.16)$ & $5.18(4.62)$ & $5.58(5.29)$ & $6.37(6.00)$ & 312 \\
\hline $9 e$ & $\mathrm{C}_{26} \mathrm{H}_{17} \mathrm{~N}_{3} \mathrm{O}_{6} \mathrm{~S}$ & $p-\mathrm{NO}_{2}$ & 77 & 118 & 499 (492.5) & $65.52(62.21)$ & $3.40(3.90)$ & $8.41(8.53)$ & $6.41(6.20)$ & 380 \\
\hline $9 f$ & $\mathrm{C}_{26} \mathrm{H}_{18} \mathrm{~N}_{2} \mathrm{O}_{5} \mathrm{~S}$ & $p-\mathrm{OH}$ & 70 & 165 & $470(460.6)$ & $66.38(65.92)$ & $3.82(4.40)$ & $5.95(6.22)$ & $6.80(6.70)$ & 360 \\
\hline & $\mathrm{C}_{27} \mathrm{H}_{20} \mathrm{~N}_{2} \mathrm{O}_{5} \mathrm{~S}$ & $p-\mathrm{OCH}_{3}$ & 76 & 65 & 484 (476.98) & $66.94(65.04)$ & $4.13(4.12)$ & $5.78(5.70)$ & $6.61(6.40)$ & 350 \\
\hline $9 \mathrm{~h}$ & $\mathrm{C}_{28} \mathrm{H}_{23} \mathrm{~N}_{3} \mathrm{O}_{4} \mathrm{~S}$ & $p-\mathrm{N}\left(\mathrm{CH}_{3}\right)$ & 87 & 98 & 497 (484.57) & $66.38(65.72)$ & $4.62(4.80)$ & $8.45(8.17)$ & $6.43(6.45)$ & 320 \\
\hline
\end{tabular}

TABLE 2: Zone of bacterial and fungal growth inhibition ( $\mathrm{mm}$ ) for compounds $\mathbf{9 a}-\mathbf{h}$.

\begin{tabular}{|c|c|c|c|c|c|c|c|c|c|}
\hline \multirow{4}{*}{ S. no } & \multirow{4}{*}{ Compounds } & \multicolumn{8}{|c|}{ Zone of inhibition } \\
\hline & & \multicolumn{4}{|c|}{ Bacteria } & \multicolumn{4}{|c|}{ Fungi } \\
\hline & & \multicolumn{2}{|c|}{ E. coli } & \multicolumn{2}{|c|}{ S. aureus } & \multicolumn{2}{|c|}{ A. niger } & \multicolumn{2}{|c|}{ R. bataticola } \\
\hline & & $10 \mu \mathrm{L}$ & $20 \mu \mathrm{L}$ & $10 \mu \mathrm{L}$ & $20 \mu \mathrm{L}$ & $10 \mu \mathrm{L}$ & $20 \mu \mathrm{L}$ & $10 \mu \mathrm{L}$ & $20 \mu \mathrm{L}$ \\
\hline 1 & $9 a$ & 11 & 13 & 29 & 31 & 27 & 29 & 19 & 23 \\
\hline 2 & $9 b$ & 11 & 12 & 30 & 31 & 24 & 26 & 18 & 24 \\
\hline 3 & $9 c$ & 10 & 11 & 30 & 31 & 27 & 29 & 11 & 13 \\
\hline 4 & 9d & 10 & 11 & 28 & 30 & 27 & 29 & 13 & 18 \\
\hline 5 & $9 e$ & 11 & 12 & 10 & 14 & 12 & 13 & 10 & 15 \\
\hline 6 & 9f & 13 & 14 & 10 & 13 & 13 & 15 & 14 & 16 \\
\hline 7 & $9 g$ & 08 & 10 & 10 & 12 & 11 & 13 & 15 & 16 \\
\hline 8 & $9 \mathrm{~h}$ & 10 & 12 & 08 & 12 & 13 & 14 & 12 & 14 \\
\hline 9 & Ampicillin & 20 & 22 & 38 & 40 & - & - & - & - \\
\hline 10 & Bavistin & - & - & - & - & 19 & 21 & 21 & 24 \\
\hline 11 & DMSO & - & - & - & - & - & - & - & - \\
\hline
\end{tabular}

Key: All results are mean of three replications.

to the maximum reaction of dye molecules with the fibres and high stability of reaction products at room temperature. The difference in each dye colours on diverse fibres could be accounted for in terms of the different structures of their reaction products with the fibres. Fibre-wise order in dyeing potential of all the dyes in terms of fixation in both dyeing treatments is silk > wool > cotton > polyester.

2.3. Mechanism of Dyeing Action and Effect of Dye Auxochromes on Dye Fixation. All the synthesized thiazolidinone derivatives are reactive dyes with two, three, or four reactive chromophores and one or two reactive auxochromes. Primary alcoholic groups of cotton and polyester fibres interact with carbonyl groups of the dyes in presence of acid to yield unstable hemiacetals or hemiketals which on nucleophilic substitution converted to stable acetals or ketals (Figure 1).

Whereas, -CONH- characteristic group of the protein fibres of silk and wool interacts with enolic and/or phenolic groups of dyes in presence of acid (Figure 2).

The better fixation of all the dyes on silk and wool than cotton and polyester fibres could be accounted for in terms of more stability of the bond(s) between dyes $\mathrm{OH}$ group(s) and silk/wool fibre substrate owing to high reducing character of phenolic or enolic group(s) than carbonyl group $(\mathrm{C}=\mathrm{O})$ of cotton and polyester. It is worth noting that electron donor ability of auxochromic substituents plays important role in dye fixation in compounds $\mathbf{9}(\mathbf{e}-\mathbf{h})$ whereas, electron donor ability of benzene ring substituents in $\mathbf{9}(\mathbf{a}-\mathbf{d})$ products is insignificant in dye fixation for unknown reasons; in $\mathbf{9}(\mathbf{e}-\mathbf{h})$ dye fixation order $\mathrm{NO}_{2}>\mathrm{OCH}_{3}>\mathrm{OH}>\mathrm{N}\left(\mathrm{CH}_{3}\right)_{2}$ is opposite to electron donor ability of auxochromic substituents. This adverse effect of electron donor ability of dye auxochromes on dye fixation owes to weakening of homopolar bond between textile substrate and dye by the electronic charge transfer by the parasubstituted auxochromic group of the dye.

\section{Experimental}

3.1. Materials and Methods. All reagents and solvents used were either Aldrich or $\mathrm{BDH}$ products and used without further purification. The progress of reactions and the purity of compounds were checked by thin-layer chromatography (TLC) using Merck silica gel $60 \mathrm{~F}_{254}$ plates, and visualization was done in UV light $(254 \mathrm{~nm})$. Yields are based on purified material and were not optimized. Melting points were determined in open glass capillaries using a digital melting point apparatus (Bibby Starling LTD, ST150SA model, U.K) and are uncorrected. The ${ }^{1} \mathrm{H}$ NMR and ${ }^{13} \mathrm{C}$ NMR spectra 


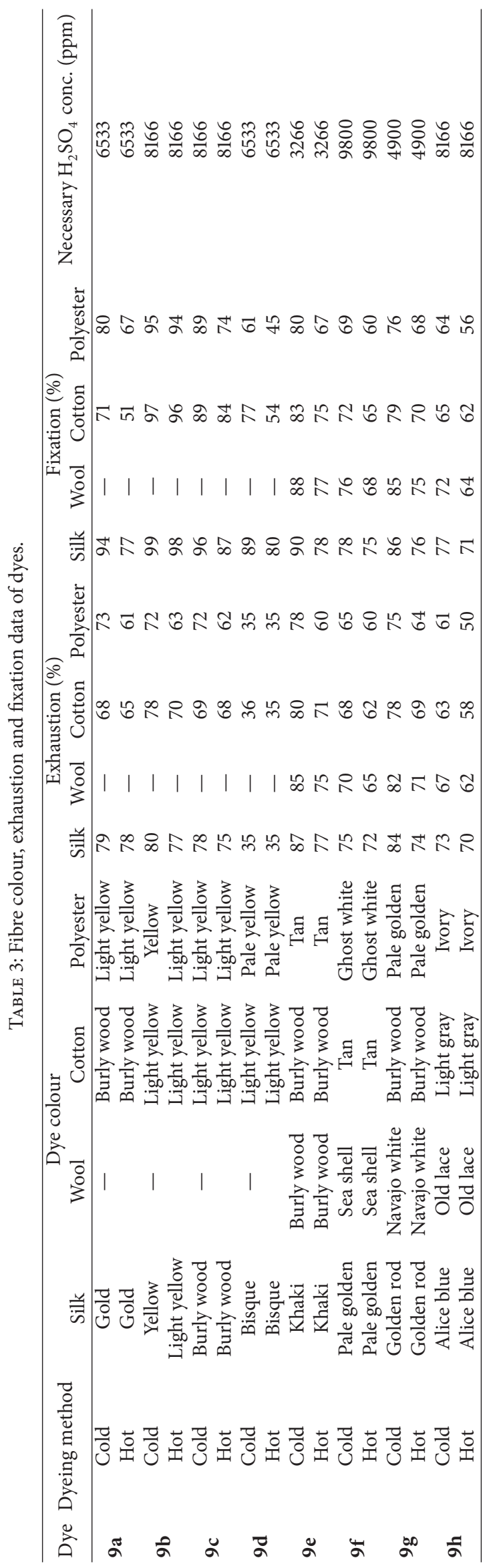




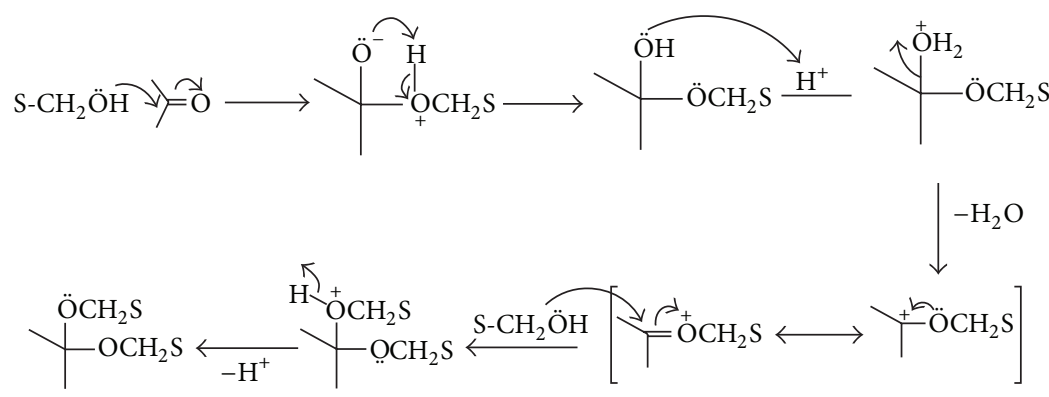

Acetal or ketal

Hemiacetal or hemiketal

Where $S$ is fibre substrate

FIGURE 1: Interaction of thiazolidinone derivative dyes with cotton and polyester fibres.

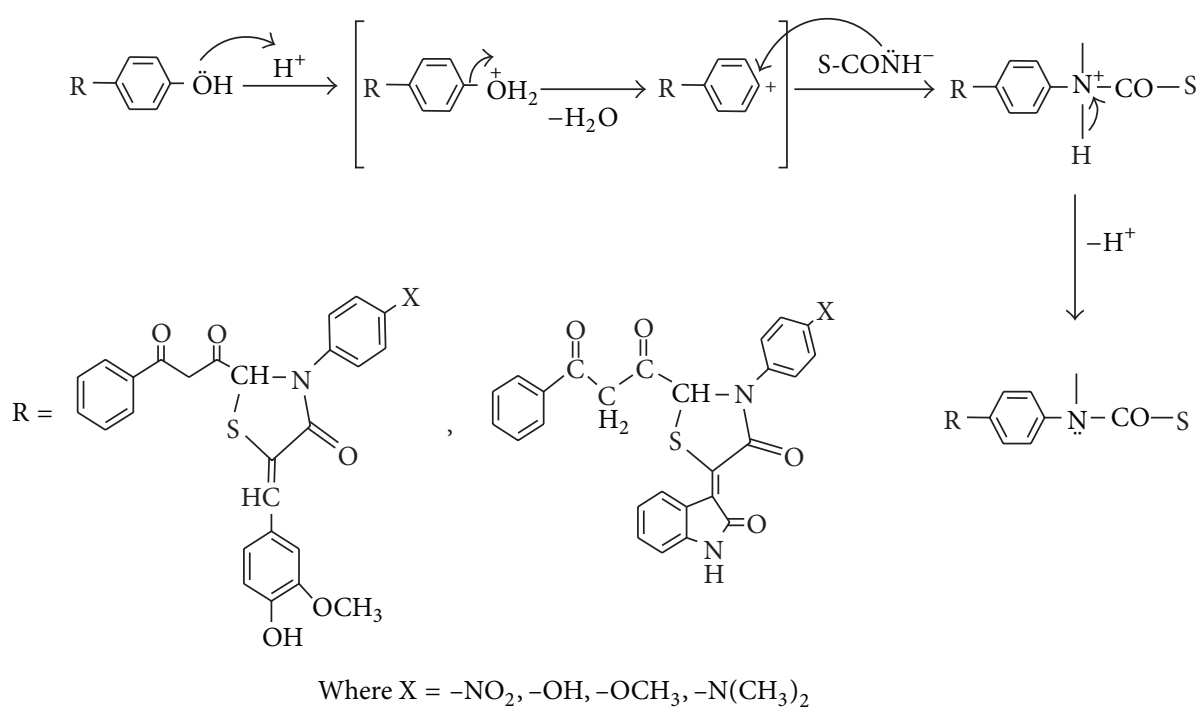

FIgURE 2: Interaction of thiazolidinone derivative dyes with silk.

were recorded on a Bruker Avance spectrometer operating at $400 \mathrm{MHz}$ in $\mathrm{DMSO} / \mathrm{CDCl}_{3}$ medium and chemical shifts are expressed as $\delta(\mathrm{ppm})$ with tetramethylsilane as internal standard. The spin multiplicities are reported as s (singlet), br s (broad singlet), d (doublet), t (triplet), q (quartet), and $\mathrm{m}$ (multiplet). The IR spectra were recorded on a FTIR-12 spectrophotometer in $\mathrm{KBr}$ medium. Elemental analyses were carried out on a Vario EL-III analyzer for C, H, N, and S contents. Molecular weights of the synthesized compounds were determined by Rast's method by using camphor as solvent.

3.2. Synthesis of Compounds. The title compounds, thiazolidinone derivatives, were synthesized by following reported procedure $[16,20]$ in four steps as follows.

3.2.1. Synthesis of 2,4-Dioxo-4-phenylbutanal [20] (2). For the synthesis of 2,4-dioxo-4-phenylbutanal [20], the reaction mixture containing $66.5 \mathrm{~g}$ selenium dioxide and $98.0 \mathrm{~g}$ of benzoylacetone (1) in 95\% ethyl alcohol (5\% water) was refluxed for $\sim 5 \mathrm{~h}$. The reaction mixture after cooling to room temperature was decanted and solvent was evaporated over water bath. The product was dissolved in ether and filtered to remove selenium. Air-dried product crystallized from ether was used for the synthesis of azomethines.

3.2.2. Synthesis of 3-Oxo-3-phenylpropanoyl azomethines [20] (4). For the synthesis of each azomethine [20], $p-\mathrm{NO}_{2}(8.6 \mathrm{~g})$, $p-\mathrm{OCH}_{3}(7.7 \mathrm{~g}), p-\mathrm{N}\left(\mathrm{CH}_{3}\right)_{2}(8.5 \mathrm{~g})$, and $p-\mathrm{OH}(6.8 \mathrm{~g})$ substituted anilines were mixed with 2,4-dioxo-4-phenylbutanal $(11.0 \mathrm{~g})(2)$ in round bottom flask containing dry ethanol and refluxed on water bath for $6 \mathrm{~h}$. Concentrated reaction mixtures were cooled in an ice bath to obtain solid products. The solids obtained were crystallized from ethanol.

3.2.3. Synthesis of 2-(3-Oxo-3-phenylpropanoyl)-3-(4substi- tuted aryl)-1-thiazolidin-4-ones [20] (6). For the synthesis of 2-(3-oxo-3-phenylpropanal)-3-(substituted aryl)-1-thiazolidin-4-ones, $p$ - $\mathrm{NO}_{2}$ (5.2 g), $p$ - $\mathrm{OCH}_{3}$ (5.0 g), $p$ $\mathrm{N}\left(\mathrm{CH}_{3}\right)_{2}(6.0 \mathrm{~g})$, and $p$-OH $(4.2 \mathrm{~g})$ substituted azomethines were mixed with $6.1 \mathrm{~mL}, 6.2 \mathrm{~mL}, 7.1 \mathrm{~mL}$, and $5.4 \mathrm{~mL}$ thioglycolic acid, respectively, in dry benzene. The reaction 
mixtures were refluxed for $8 \mathrm{~h}$ and concentrated to half of their volume over water bath and then neutralized with aqueous sodium bicarbonate solution. All the contents of reaction mixtures were poured in ice cold water and filtered. The solids washed with water were dried and purified by crystallization from benzene.

3.2.4. General Procedure for the Synthesis of 5-(4-Hydroxy3-methoxybenzylidene)-2-(3-oxo-3-phenylpropanoyl)-3-(substituted aryl)-1-thiazolidin-4-ones $(\mathbf{9 a}-\boldsymbol{d})$. To synthesize title thiazolidinone dyes, vanillin $(0.01 \mathrm{~mol}, 1.52 \mathrm{~g})$ and each of the 2-(3-oxo-3-phenylpropanal)-3-(substituted aryl)-1thiazolidin-4-ones $(0.01 \mathrm{~mol})$ were mixed together in dry methanol and fused sodium acetate $(2.0 \mathrm{~g})$ was added to each reaction mixture followed by refluxing for $8 \mathrm{~h}$. Solids as residues of products obtained on evaporation of solvent were washed with water repeatedly and dried in air. All the products were crystallized from methanol.

3.2.5. 5-(4-Hydroxy-3-methoxybenzlidene)-2-(3-oxo-3-phenylpropanoyl)-3-(p-nitrophenyl)-1-thiazolidin-4-one (9a). Yield $65 \%$, colour olive, melting point $96^{\circ} \mathrm{C}$, IR $\left(\mathrm{KBr}, \mathrm{cm}^{-1}\right)$ : v $3482(\mathrm{OH}), 1631(\mathrm{C}=\mathrm{O}), 1300(\mathrm{C}-\mathrm{N}) ;{ }^{1} \mathrm{H}$ NMR $\delta 9.7$ (s, H, $\mathrm{OH}), \delta 3.8\left(\mathrm{~s}, 2 \mathrm{H}\right.$, chain $\left.-\mathrm{CH}_{2}\right), 7.5(\mathrm{~s}, 1 \mathrm{H}, \mathrm{CH}-\mathrm{N}), \delta 6.6-7.5$ $\left(\mathrm{m}\right.$, aromatic Hs), $\delta 6.6(\mathrm{~s}, 1 \mathrm{H}, \mathrm{C}=\mathrm{CH}) ;{ }^{13} \mathrm{C}$ NMR $\delta 40,56$, 136, 158, 191.

3.2.6. 5-(4-Hydroxy-3-methoxybenzlidene)-2-(3-oxo-3-phenylpropanoyl)-3-(p-hydroxylphenyl)-1-thiazolidin-4-one (9b). Yield $72 \%$, colour yellow, melting point $195^{\circ} \mathrm{C}$, IR $(\mathrm{KBr}$, $\left.\mathrm{cm}^{-1}\right): v 3286(\mathrm{OH}), 1645(\mathrm{C}=\mathrm{O}), 1331(\mathrm{C}-\mathrm{N}) ;{ }^{1} \mathrm{H}$ NMR $\delta 9.7$ $(\mathrm{s}, 2 \mathrm{H}, 2 \mathrm{OH}), \delta 3.5\left(\mathrm{~s}, 2 \mathrm{H}\right.$, chain $\left.-\mathrm{CH}_{2}\right), 7.5(\mathrm{~s}, 1 \mathrm{H}, \mathrm{CH}-\mathrm{N})$, $\delta$ 6.8-7.4 (m, aromatic $\mathrm{Hs}), \delta 6.8(\mathrm{~s}, 1 \mathrm{H}, \mathrm{C}=\mathrm{CH}) ;{ }^{13} \mathrm{C}$ NMR $\delta$ 20, 40, 131, 156, 187.

3.2.7. 5-(4-Hydroxy-3-methoxybenzlidene)-2-(3-oxo-3-phenylpropanoyl)-3-(p-methoxyphenyl)-1-thiazolidin-4-one (9c). Yield $74 \%$, colour brown, melting point $39^{\circ} \mathrm{C}$, IR $\left(\mathrm{KBr}, \mathrm{cm}^{-1}\right)$ : v $3330(\mathrm{OH}), 1672(\mathrm{C}=\mathrm{O}), 1291(\mathrm{C}-\mathrm{N}) ;{ }^{1} \mathrm{H}$ NMR $\delta 9.8(\mathrm{~s}, \mathrm{H}$, $\mathrm{OH}), \delta 4.0\left(\mathrm{~s}, 2 \mathrm{H}\right.$, chain $\left.-\mathrm{CH}_{2}\right), 7.4(\mathrm{~s}, 1 \mathrm{H}, \mathrm{CH}-\mathrm{N}), \delta 7.0-7.4$ (m, aromatic Hs), $\delta 6.9$ (s, $1 \mathrm{H}, \mathrm{C}=\mathrm{CH}) ;{ }^{13} \mathrm{C}$ NMR $\delta 20,56$, 128, 157, 191.

3.2.8. 5-(4-Hydroxy-3-methoxybenzlidene)-2-(3-oxo-3-phenylpropanoyl)-3-( $p$-N,N-dimethylamino phenyl)-1-thiazolidin-4-one (9d). Yield 84\%, colour saddle brown, melting point $59^{\circ} \mathrm{C}$, IR $\left(\mathrm{KBr}, \mathrm{cm}^{-1}\right): v 3320(\mathrm{OH}), 1671(\mathrm{C}=\mathrm{O}), 1325$ $(\mathrm{C}-\mathrm{N}) ;{ }^{1} \mathrm{H}$ NMR $\delta 9.8(\mathrm{~s}, \mathrm{H}, \mathrm{OH}), \delta 4.0\left(\mathrm{~s}, 2 \mathrm{H}\right.$, chain $\left.-\mathrm{CH}_{2}\right)$, $7.5(\mathrm{~s}, 1 \mathrm{H}, \mathrm{CH}-\mathrm{N}), \delta 6.8-7.5(\mathrm{~m}$, aromatic Hs), $\delta 6.7$ (s, $1 \mathrm{H}$, $\mathrm{C}=\mathrm{CH}), \delta 3.0\left(\mathrm{~s}, 6 \mathrm{H}, \mathrm{N}\left(\mathrm{CH}_{3}\right)_{2}\right) ;{ }^{13} \mathrm{C} \mathrm{NMR} \delta 20,41,131,164$, 191.

3.2.9. General Procedure for the Synthesis of 3-(2-(3-Oxo3-phenylpropanoyl)-3-(substituted aryl)-4-oxothiazolidin5-ylidene)indolin-2-ones $(\mathbf{9} \boldsymbol{e}-\boldsymbol{h})$. For synthesis of indigoid thiazolidinones, isatin $(1.47 \mathrm{gm}, 0.01 \mathrm{~mol})$ and 2-(3-oxo-3phenyl propanoyl)-3-(substituted aryl)-1-thiazolidin-4-ones
$(0.01 \mathrm{~mol})$ were mixed together in dry ethanol and fused sodium acetate $(5.0 \mathrm{~g})$ was added to the reaction mixtures followed by refluxing for $6 \mathrm{~h}$. Filtrates of reaction mixtures were evaporated on water bath and residues washed with water repeatedly were crystallized from ethanol and dried in air.

3.2.10. 3-(2-(3-Oxo-3-phenylpropanoyl)-3-(p-nitro phenyl)4-oxothiazolidin-5-ylidene)indolin-2-one (9e). Yield 77\%, colour sandy brown, melting point $117-118^{\circ} \mathrm{C}$, IR $\left(\mathrm{KBr}, \mathrm{cm}^{-1}\right)$ : v $3480(\mathrm{NH}), 1735(\mathrm{C}=\mathrm{O}), 1302(\mathrm{CN}), 697(\mathrm{CS}), 2874(\mathrm{C}-\mathrm{H}$ of chain $\left.\mathrm{CH}_{2}\right) ;{ }^{1} \mathrm{H}$ NMR $\delta 2.5\left(\mathrm{~s}, 2 \mathrm{H}\right.$, chain $\left.-\mathrm{CH}_{2}\right), 11(\mathrm{~s}, 1 \mathrm{H}$, $\mathrm{NH}), \delta$ 6.5-8.5 (m, aromatic Hs); ${ }^{13} \mathrm{C}$ NMR $\delta 20,40,130$, $160,187$.

3.2.11. 3-(2-(3-Oxo-3-phenylpropanoyl)-3-(p-hydroxyl phenyl)-4-oxothiazolidin-5-ylidene)indolin-2-one (9f). Yield $70 \%$, colour peru, melting point $164-165^{\circ} \mathrm{C}$, IR $\left(\mathrm{KBr}, \mathrm{cm}^{-1}\right)$ : v $3495(\mathrm{NH}), 3195(\mathrm{OH}), 1730(\mathrm{C}=\mathrm{O}), 1331(\mathrm{CN}), 673(\mathrm{CS})$, $2809\left(\mathrm{C}-\mathrm{H}\right.$ of chain $\left.\mathrm{CH}_{2}\right) ;{ }^{1} \mathrm{H}$ NMR $\delta 5.6(\mathrm{~s}, \mathrm{H}, \mathrm{OH}), \delta 2.5$ $\left(\mathrm{s}, 2 \mathrm{H}\right.$, chain $\left.-\mathrm{CH}_{2}\right), 9.7(\mathrm{~s}, 1 \mathrm{H}, \mathrm{NH}), \delta 6.5-8.0(\mathrm{~m}$, aromatic $\mathrm{Hs}) ;{ }^{13} \mathrm{C}$ NMR $\delta 20,40,140,160,187$.

3.2.12. 3-(2-(3-Oxo-3-phenylpropanoyl)-3-(p-methoxy phenyl)-4-oxothiazolidin-5-ylidene)indolin-2-one (9g). Yield $76 \%$, colour orange, melting point $64-65^{\circ} \mathrm{C}$, IR $\left(\mathrm{KBr}, \mathrm{cm}^{-1}\right)$ : $\nu 3437(\mathrm{NH}), 1728(\mathrm{C}=\mathrm{O}), 1332(\mathrm{CN}), 694(\mathrm{CS}), 2836(\mathrm{C}-\mathrm{H}$ of chain $\left.\mathrm{CH}_{2}\right) ;{ }^{1} \mathrm{H}$ NMR $\delta 2.0\left(\mathrm{~s}, 2 \mathrm{H}\right.$, chain $\left.-\mathrm{CH}_{2}\right), 8.5(\mathrm{~s}, 1 \mathrm{H}$, $\mathrm{NH}), \delta 6.5-8.0(\mathrm{~m}$, aromatic $\mathrm{Hs}), \delta 2.5\left(\mathrm{~s}, 3 \mathrm{H}, \mathrm{OCH}_{3}\right) ;{ }^{13} \mathrm{C}$ NMR $\delta$ 23, 60, 134, 152, 174.

3.2.13. 3-(2-(3-Oxo-3-phenylpropanoyl)-3-(p-N,N-dimethylaminophenyl)-4-oxothiazolidin-5-ylidene)indolin-2-one (9h). Yield $87 \%$, colour dim gray, melting point $97-98^{\circ} \mathrm{C}$, IR $(\mathrm{KBr}$, $\left.\mathrm{cm}^{-1}\right): v 3461(\mathrm{NH}), 1730(\mathrm{C}=\mathrm{O}), 1328(\mathrm{CN}), 694(\mathrm{CS}), 2924$ $\left(\mathrm{C}-\mathrm{H}\right.$ of chain $\left.\mathrm{CH}_{2}\right) ;{ }^{1} \mathrm{H}$ NMR $\delta 2.3\left(\mathrm{~s}, 2 \mathrm{H}\right.$, chain $\left.-\mathrm{CH}_{2}\right)$, 7.9 (s, 1H, NH), $\delta$ 6.0-7.7 (m, aromatic Hs), $\delta 1.3(\mathrm{~s}, 6 \mathrm{H}$, $\left.\mathrm{N}\left(\mathrm{CH}_{3}\right)_{2}\right) ;{ }^{13} \mathrm{C}$ NMR $\delta 22,41,130,185$.

3.3. Antimicrobial Studies. The synthesized compounds were tested in vitro for their antimicrobial activities by using the paper disc diffusion technique against two important bacteria, Escherichia coli and Staphylococcus aureus, using Muller Hinton agar (MHA) medium and antifungal activity against two common fungi, Aspergillus niger and Rhizoctonia bataticola, using potato dextrose agar (PDA) medium. Ampicillin, a standard drug, was used as reference in bactericidal and Bavistin, a standard fungicide, was used as reference in fungicidal studies. From inhibition zone data antimicrobial activities of the compounds were critically examined.

3.4. Preparation of Inoculums. The test bacterial strains, Escherichia coli (Gram-negative) and Staphylococcus aureus (Gram-positive), were transferred from the stock cultures and streaked on MHA plate and incubated for $24 \mathrm{~h}$ at $37^{\circ} \mathrm{C}$. Then, the bacteria were transferred using inoculating loop to autoclaved MHA that was cooled to about $45^{\circ} \mathrm{C}$ in a water 
bath and mixed by gently swirling the flasks. The medium was then poured to sterilized Petri dishes, allowed to solidify, and used for the biotest. For test fungi, mycelia plugs from stock cultures were transferred to PDA plates and incubated for 6 days. Then, spores of the test fungi were harvested by washing the surface of the colony using $10 \mathrm{~mL}$ sterile distilled water and transferred to $50 \mathrm{~mL}$ autoclaved PDA cooled to about $45^{\circ} \mathrm{C}$ in a water bath. The media containing spore suspension were poured to sterilized plates, allowed to solidify, and were used for the disc diffusion bioassay.

3.5. Preparation of Sample Solutions. The synthesized thiazolidinone derivatives were prepared by dissolving $10 \mathrm{mg}$ in $2 \mathrm{~mL}$ of dimethylsulphoxide and used for testing.

3.6. Testing for Antifungal Activity. Filter paper discs of $6 \mathrm{~mm}$ diameter placed in a beaker were sterilized in an oven at $180^{\circ} \mathrm{C}$ for $1 \mathrm{~h}$. Then $10 \mu \mathrm{L}$ and $20 \mu \mathrm{L}$ of solution of compounds were pipetted to the discs in three replications. After allowing the solvent to evaporate, the paper discs impregnated with the samples were then transferred with sterilized forceps to PDA seeded with spore suspension of test fungi as described above. The Petri dishes were incubated at $25^{\circ} \mathrm{C}$ for $2-3$ days. The entire test was performed in triplicate. The antifungal activity was evaluated by measuring the zone of inhibition against the test organism.

3.7. Testing for Antibacterial Activity. Similar procedures done for antifungal activity test were followed in antibacterial studies except the paper discs were transferred to nutrient agar plate seeded with bacteria and incubated at $37^{\circ} \mathrm{C}$ for Staphylococcus aureus and $28^{\circ} \mathrm{C}$ for Escherichia coli for $25 \mathrm{~h}$.

3.8. Dyeing Studies. Solutions of thiazolidinone dyes were prepared by dissolving $10 \mathrm{mg}$ of each compound directly in $\mathrm{MeOH}-\mathrm{H}_{2} \mathrm{O}(1: 1 \mathrm{v} / \mathrm{v})$ for $\lambda_{\text {max }}$ determination. At difference of $2 \mathrm{~nm}$ optical density was measured and graphs were plotted in wavelength versus optical density of solution to determine $\lambda_{\text {max }}$ of each sample.

For quantitative studies standard solutions of thiazolidinones were prepared by dissolving known quantities of samples in known volumes of the solvent, $\mathrm{MeOH}-\mathrm{H}_{2} \mathrm{O}(1: 1$ $\mathrm{v} / \mathrm{v})$.

For finding out necessary $\mathrm{H}_{2} \mathrm{SO}_{4}$ concentration for producing maximum colour intensity of each dye, six equiconcentrated solutions of each dye sample were prepared in $\mathrm{MeOH}-\mathrm{H}_{2} \mathrm{O}(1: 1 \mathrm{v} / \mathrm{v})$ solvent containing different quantities of acid and optical densities were measured at $\lambda_{\max }$ of each dye. From the highest value of optical density of the dye at its $\lambda_{\max }$ requisite concentration of acid necessary for producing maximum colour was determined. For the preparation of calibration curves, optical density at $\lambda_{\max }$ of each dye solution at different concentrations containing requisite quantity of acid was measured.

3.9. Dying and Postdyeing Treatment. Two of the four prewashed white cloth pieces of $8 \mathrm{~cm} \times 8 \mathrm{~cm}$ size of silk, wool, cotton, and polyester were dipped in $10 \mathrm{~mL}$ of $500 \mathrm{ppm}$ dye solution in each beaker at room temperature and $80 \pm 5^{\circ} \mathrm{C}$ containing necessary concentration of $\mathrm{H}_{2} \mathrm{SO}_{4}$ separately and were left for $1 \mathrm{~h}$, squeezed, and dried in sunlight. Then two pieces of each fibre, dyed by each dye using cold and hot methods, were washed with water and dried in sunlight.

\subsection{Determination of Total Dye Exhaustion and Fixation of}

Dye. For determination of total dye exhaustion, one piece of each fibre dyed by each method was squeezed and optical density of extracted solution of each dye was measured to find out concentration from its calibration curve prepared under similar conditions of temperature and solvent; from the concentration of extract total dye exhaustion was calculated. Dyed dry clothes were dipped in $20 \mathrm{~mL}$ water and were left for 30 minutes and then squeezed and optical density of the extract was measured and concentration was determined from calibration curve to know the fixation of dye on each fibre. Dye exhaustion $(\% E)$ and fixation $(\% F)$ were calculated using the following equations [21]:

$$
\begin{gathered}
\% E=\frac{\left(D_{o}-D_{f}\right)}{D_{o}} \times 100, \\
\% F=\frac{\left(D_{o}-D_{f}-D_{e}\right)}{D_{o}-D_{f}} \times 100,
\end{gathered}
$$

where $D_{0}, D_{f}$, and $D_{e}$ are concentration of dye before and after dyeing and amount of extracted dyes, respectively.

\section{Conclusion}

Based on our experimental findings, all the new triaryl substituted derivatives containing thiazolidinone moiety exhibiting excellent bactericidal and fungicidal and dyeing potentials could be proposed for dyeing and antimicrobial finishing for silk, wool, cotton, and polyester fabrics.

\section{Conflict of Interests}

The authors declare that there is no conflict of interests regarding the publication of this paper.

\section{Acknowledgments}

The authors wish to thank Departments of Chemistry and Plant Sciences, Haramaya University, for providing laboratory facilities and antimicrobial studies, respectively. Indian Institute of Technology, Roorkee, India, for elemental analysis and IR spectra, Addis Ababa University for ${ }^{1} \mathrm{H}$ NMR and

${ }^{13} \mathrm{C}$ NMR spectra, and Ministry of Education for providing financial assistance are also gratefully acknowledged.

\section{References}

[1] A. V. Dobaria, J. R. Patel, J. V. Padaliya, and H. H. Parekh, "Thiazolidinones bearing chloroquinoline nucleus as potential antimicrobial agents," Indian Journal of Heterocyclic Chemistry, vol. 11, no. 2, pp. 115-118, 2001. 
[2] S. G. Kucukguzel, E. E. Oruc, S. Rollas, F. Sahin, and A. Ozbek, "Synthesis, characterisation and biological activity of novel 4-thiazolidinones, 1,3,4-oxadiazoles and some related compounds," European Journal of Medicinal Chemistry, vol. 37, no. 3, pp. 197-206, 2002.

[3] R. K. Rawal, Y. S. Prabhakar, S. B. Katti, and E. de Clercq, "2(aryl)-3-furan-2-ylmethyl-thiazolidin-4-ones as selective HIVRT Inhibitors," Bioorganic and Medicinal Chemistry, vol. 13, no. 24, pp. 6771-6776, 2005.

[4] M. G. Vigorita, R. Ottanà, F. Monforte et al., "Synthesis and antiinflammatory, analgesic activity of 3,3'-(1,2-ethanediyl)-bis[2aryl-4-thiazolidinone] chiral compounds-part 10," Bioorganic \& Medicinal Chemistry Letters, vol. 11, no. 21, pp. 2791-2794, 2001.

[5] B. Goel, T. Ram, R. Tyagi et al., "2-substituted-3-(4-bromo-2carboxyphenyl)-5-methyl-4-thiazolidinones as potential antiinflammatory agents," European Journal of Medicinal Chemistry, vol. 34, no. 3, pp. 265-269, 1999.

[6] A. Solankee, K. Kapadia, I. Thakor, J. Patel, and S. Lad, "Synthesis and biological evaluation of some new chalcones and their derivatives," Asian Journal of Chemistry, vol. 16, no. 2, pp. 921-927, 2004.

[7] P. Mishra, K. P. Namdeo, S. Jain, and S. Jain, "Synthesis and antimicrobial activity of 4-thiazolidinones," Asian Journal of Chemistry, vol. 11, no. 1, pp. 55-58, 1999.

[8] D. S. Nair and A. C. Shah, "Synthesis of 5-thiazolidinone derivatives of (R) \& (S)-2-aminobutanols," Indian Journal of Heterocyclic Chemistry, vol. 16, no. 3, pp. 231-234, 2007.

[9] C. D. Diulatbad and G. G. Bhat, "Synthesis and antimicrobial studies of 4-thiazolidinone derivatives from 2-bromohexanoic acid-part-II," Indian Journal of Heterocyclic Chemistry, vol. 9, pp. 157-158, 1999.

[10] D. Gebretekle, A. Tadesse, R. K. Upadhyay, and A. Dekebo, "Synthesis, characterization and antimicrobial evaluation of some schiff bases and their thiazolidinone products," Oriental Journal of Chemistry, vol. 28, no. 4, pp. 1791-1796, 2012.

[11] V. P. M. Rehman, S. H. Mukhtar, W. Ansari, and G. Lemiere, "Synthesis, stereochemistry and biological activity of some novel long alkyl chain substituted thiazolidin-4-ones and thiazan-4-one from 10-undecenoic acid hydrazide," European Journal of Medicinal Chemistry, vol. 40, no. 2, pp. 173-184, 2005.

[12] G. S. Singh and B. Molotsi, "Synthesis of 2-azetidinones from 2-diazo-1, 2-diarylethanones and $\mathrm{N}$-(2-thienylidene)imines as possible antimicrobial agents," Il Farmaco, vol. 60, no. 9, pp. 727-730, 2005.

[13] V. Vats, R. K. Upadhyay, and P. Sharma, "Synthesis and antifungal activities of 2-ketophenyl-3-substituted aryl-1-thiazolidin4-ones," International Journal of Theoretical \& Applied Sciences, vol. 1, pp. 24-26, 2009.

[14] D. S. Tripathi, A. R. Mishra, R. M. Mishra, D. Singh, and A. K. Dwivedi, "Synthesis and fungitoxicity of some new thiadiazolos-triazine derivatives," Indian Journal of Heterocyclic Chemistry, vol. 16, no. 2, pp. 117-120, 2006.

[15] R. Sinha, S. P. Garg, and P. Sah, "Synthesis and biological activities of some 5-(2-arylamino-1,3,4-thiadiazolo)-thioazo substituted sulphonamides and related compounds," Oriental Journal of Chemistry, vol. 20, no. 1, pp. 131-134, 2004.

[16] R. K. Upadhyay, S. Attri, S. Upadhyay, and H. K. Tiwari, "Synthesis and dyeing action of novel thioindigoid reactive dyes," Asian Journal of Chemistry, vol. 23, no. 7, pp. 3127-3129, 2011.
[17] M. Mamo, A. T. Mengesha, R. K. Upadhyay, and A. Dekebo, "Studies on antimicrobial and dyeing potentials of some new oxazolidinone derivatives," Journal of Pharmacy Research, vol. 5, p. 5543, 2012.

[18] R. K. Upadhyay, N. Agarwal, and G. Mishra, "Synthesis of aryl-2-(alpha-hydroxy)phenylketo-4-thiazolidinones as dyes," Journal of the Indian Chemical Society, vol. 72, no. 12, pp. 849$852,1995$.

[19] A. A. El-Bindary, A. Z. El-Sonbati, A. El-Dissouky, and A. S. Hilali, "Stereochemistry, structural and models of novel 5- $\left(4^{\prime}\right.$ derivatives phenyldiazo)-3-phenyl-2-thioxo-4-thiazolidinone complexes," Spectrochimica Acta A, vol. 58, no. 7, pp. 1365-1374, 2002.

[20] S. Upadhyay, [Ph.D. thesis], C.C.S. University, Meerut, India, 2005.

[21] M. Tutak and A. O. Özdemir, "Reactive dyeing of cationized cotton: effects on the dyeing yield and the fastness properties," Journal of Applied Polymer Science, vol. 119, no. 1, pp. 500-504, 2011. 

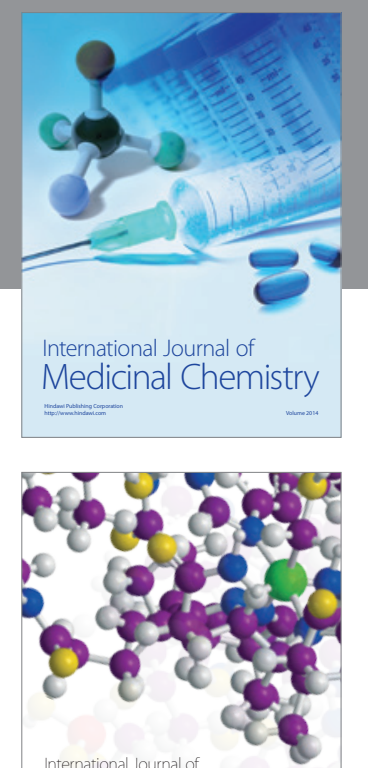

\section{Carbohydrate} Chemistry

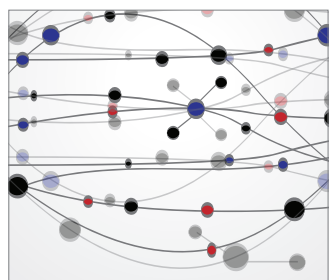

The Scientific World Journal
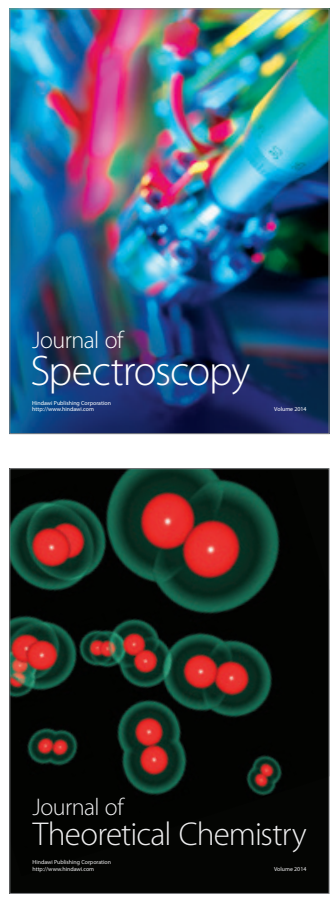
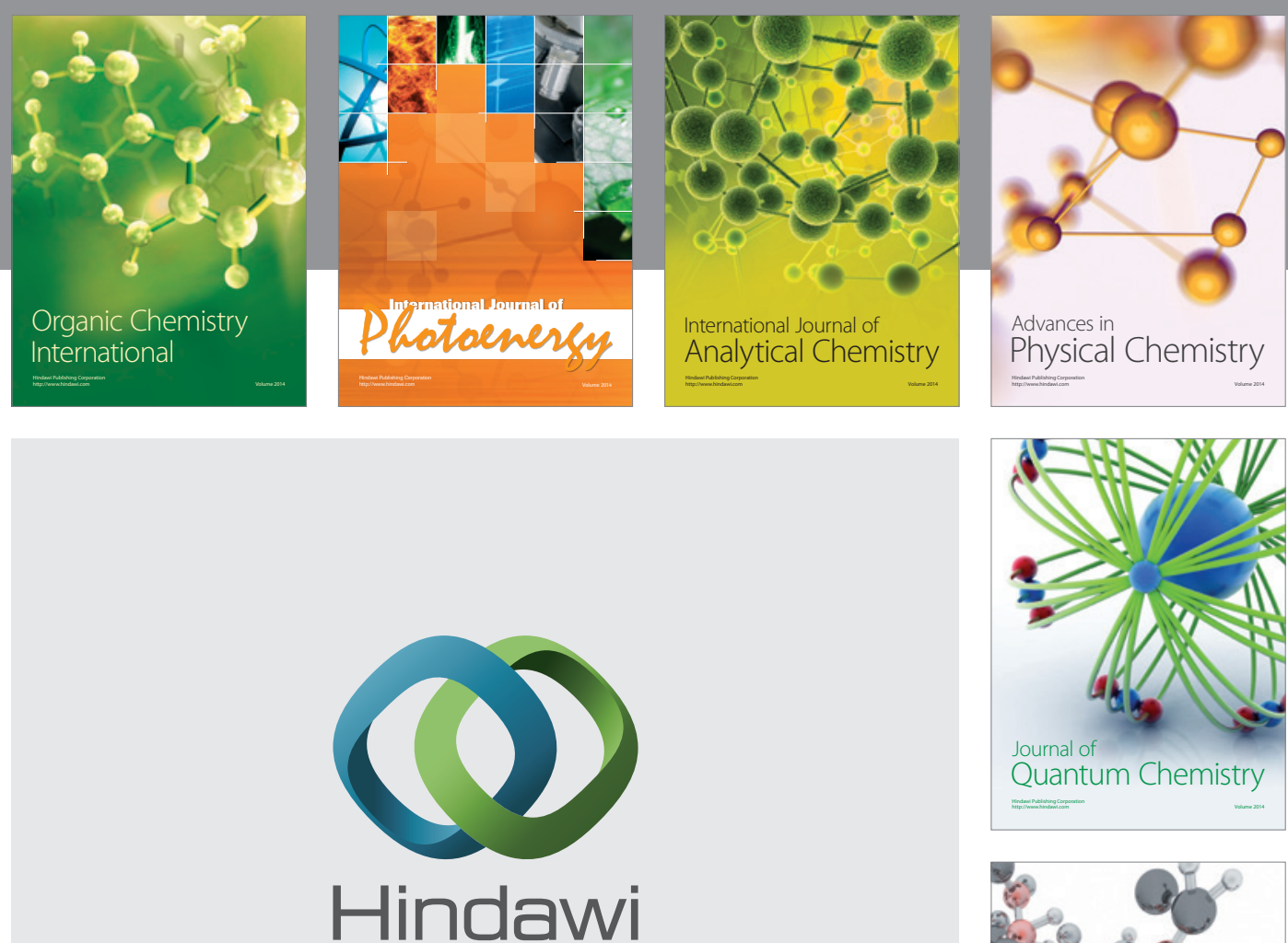

Submit your manuscripts at

http://www.hindawi.com

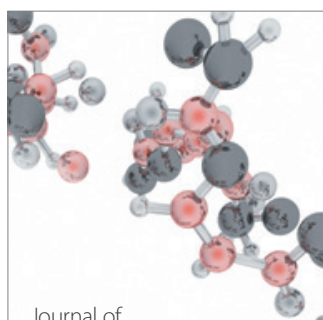

Analytical Methods

in Chemistry

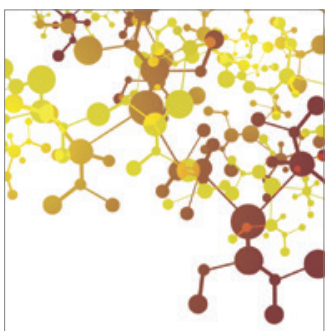

Journal of

Applied Chemistry

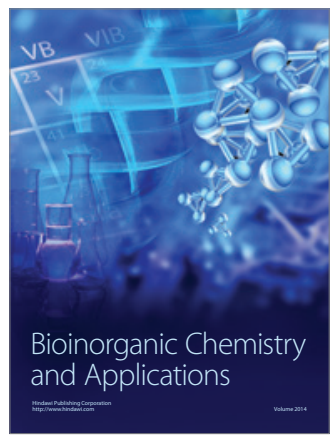

Inorganic Chemistry
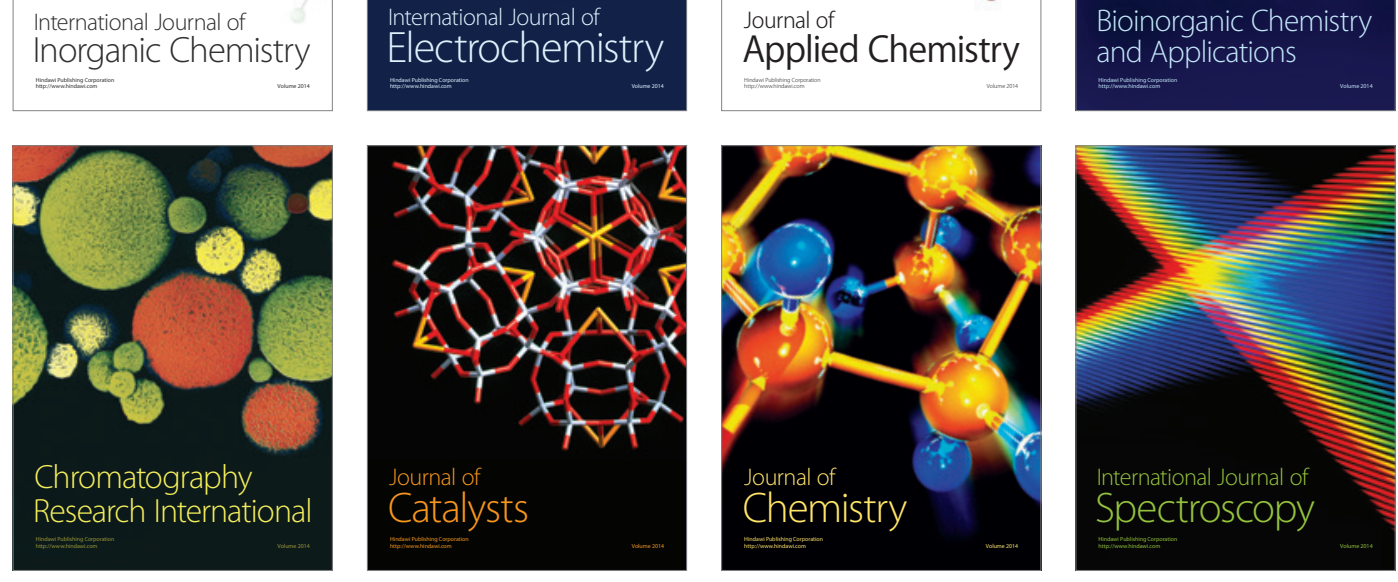